\title{
PENGARUH KEMAMPUAN DAN MOTIVASI TERHADAP KINERJA KARYAWAN (STUDI KASUS DI BAGIAN PRODUKSI PT SANG HYANG SERI (PERSERO) KANTOR REGIONAL III WILAYAH JAWA TIMUR) \\ Sri Karuniari Nuswardhani \\ Dosen Fakultas Pertanian Universitas Yudharta Pasuruan
}

\begin{abstract}
ABSTRAK
Pengaruh Kemampuan dan Motivasi terhadap Kinerja Karyawan (Studi Kasus di Bagian Produksi PT Sang Hyang Seri (Persero) Kantor Regional III Wilayah Jawa Timur). Tujuan penelitian ini adalah untuk (1) menganalisis kemampuan karyawan, (2) menganalisis motivasi karyawan, (3) menganalisis pengaruh kemampuan dan motivasi terhadap kinerja karyawan. Metode yang digunakan merupakan metode diskriptif. Responden dalam penelitian ini berjumlah 38 karyawan bagian Produksi PT Sang Hyang Seri (Persero) Kantor Regional III wilayah Jawa Timur yang ditentukan secara sensus. Dipergunakan alat analisis : regresi dan analisis jalur. Kemampuan dan Motivasi berpengaruh positif dan signifikan terhadap kinerja karyawan. Kemampuan berpengaruh langsung maupun tidak langsung melalui motivasi terhadap kinerja karyawan. Motivasi berpengaruh langsung maupun tidak langsung melalui kemampuan terhadap kinerja karyawan. Kemampuan dan motivasi berpengaruh terhadap kinerja karyawan sebesar 73,43\%, sedangkan 26,57\% dipengaruhi oleh variabel lain. Kata Kunci : Kemampuan, Motivasi, dan Kinerja Karyawan
\end{abstract}

\section{ABSTRACT}

Effect of Ability and Motivation on Employee Performance (Case Study at Production Department of PT Sang Hyang Seri (Persero) Regional Office III East Java). The purpose of this study was to (1) analyze the ability of employees, (2) analyze the motivation of employees and (3) analyze the influence of ability and motivation on the employee's performance. The method used in this research was descriptive method. The respondents were 38 employees at Production Department of PT Sang Hyang Seri (Persero) Regional Office III in East Java, which determined by the census. Analysis tools used in this study was the regression and path analysis. The result showed that ability and motivation had positive and significant impact on employee's performance. The ability had direct and indirect effect on employee's performance through motivation. The motivation had direct and indirect effect on employee's performance through the ability. The ability and motivation affect the employee's performance at $73.43 \%$, while $26.7 \%$ influenced by other variables.

Keywords : Ability, Motivation, and Employee Performance.

\section{PENDAHULUAN}

Dalam mempertahankan kelangsungan hidupnya, manusia berusaha memenuhi kebutuhan primer yaitu makanan. Dalam sejarah hidup manusia dari tahun ke tahun mengalami perubahan yang diikuti pula oleh perubahan makanan pokok. Hal ini dibuktikan di beberapa daerah yang semula makanan pokoknya ketela, sagu, jagung akhirnya beralih makan nasi.(Warta 
Litbang, 2008)

Padi merupakan bahan makanan yang menghasilkan beras. Beras adalah salah satu bahan makanan yang mengandung gizi dan penguat yang cukup bagi tubuh manusia, sebab didalamnya terkandung bahan yang mudah diubah menjadi energi. Oleh karena itu padi disebut juga makanan energi.

\section{Melalui program Revitalisasi} Pertanian yang dicanangkan oleh Presiden RI pada tahun 2005, pemerintah telah berketetapan untuk menempatkan sektor pertanian sebagai penggerak pembangunan nasional, menempatkan pertanian sebagai sektor prioritas, yang didukung oleh sektor lainnya. Akselerasi pembangunan pertanian memerlukan dukungan sistem perbenihan yang baik. Keberhasilan pengembangan pangan sangat ditentukan oleh ketersediaan benih dalam jumlah, kualitas, waktu dan harga yang tepat. Pemerintah telah memberikan perhatian serius terhadap perbenihan dan pembibitan baik yang berkaitan dengan sistem pengembangannya, penangkaran, distribusi, pembinaan, sistem cadangan, dan mekanisme pengadaannya termasuk subsidi.

Pemerintah mendorong pengembangan industri perbenihan, karena selain memperkuat mata rantai sistem pertanian juga memperkuat bisnis yang menjanjikan keuntungan yang cukup besar. Di beberapa negara peranan seed industry mencapai lebih dari $25 \%$ dari total PDB yang dihasilkan oleh sektor pertanian.

Untuk meningkatkan produktivitas benih yang cukup dan memadai diperlukan usaha antara lain :

1. Penggunaan benih unggul dan berkualitas

2. Ketersediaan Sumber Daya Manusia yang memadai

3. Dukungan dari Pemerintah.

Sejalan dengan pertumbuhan dan perkembangan kehidupan, masalah Performance Appraisal / Penilaian Kinerja merupakan masalah yang menarik untuk dikaji dan diungkap, karena pada dasarnya manusia selalu bergerak, maju dan berkembang dari waktu ke waktu. Sementara itu, kebutuhan manusia yang berkualitas meningkat dengan pesatnya, namun ketersediaan sumber daya yang berkualitas sesuai dengan kebutuhan belum mampu mengimbanginya, sehingga terjadi jarak yang cukup jauh antara kebutuhan dengan sumber daya manusia yang tersedia.

PT Sang Hyang Seri (Persero) merupakan produsen benih padi nasional di Indonesia, mempunyai Visi : menjadi perusahaan agroindustri benih nasional berkelas dunia; dan mempunyai Misi : Menghasilkan benih pertanian bermutu tinggi dan usaha lainnya yang langsung menunjang kesinambungan usaha; dan mempunyai Strategi Operasi : Industri 
Benih sebagai lokomotif usaha agribisnis. PT Sang Hyang Seri berkantor pusat di Jakarta, dan mempunyai 6 (enam) wilayah Regional di seluruh Indonesia; yaitu :

1. Kantor Regional I : di Sukamandi, Subang, Jawa Barat.

2. Kantor Regional II : di Klaten

3. Kantor Regional III : di Malang

4. Kantor Regional IV : di Medan

5. Kantor Regional V : di Lampung Timur

6. Kantor Regional VI : di Sidrap, Sulawesi Selatan.

Penelitian ini, difokuskan pada Kantor Regional (KR) III khususnya bidang Produksi. KR III ini berpusat di Kota Malang, sebagian besar daerah kerjanya di sekitar Jawa Timur, dan berkantor pusat di Jl. Ciliwung no.25 Malang, merupakan wilayah kerja yang mendapat penilaian Baik dari hasil evaluasi per tahun di lingkungan wilayah kerja PT. Sang Hyang Seri (persero) se Indonesia.

Wilayah kerja PT SHS (Persero) Kantor Regional III Malang meliputi beberapa Kantor Cabang :

1. Pasuruan

2. Nganjuk

3. Jember

4. Pujon

5. Satuan Tugas Bali \& NTB, serta Satuan Tugas NTT

Untuk mewujudkan Visi Misi perusahaan, , diperlukan dukungan Kinerja Karyawan yang baik dan tangguh, karena manusia selalu berperan aktif dan dominan dalam setiap kegiatan organisasi. Di dalam Manajemen Sumberdaya Manusia, peran manusia menjadi perencana, pelaku, dan penentu terwujudnya tujuan organisasi. Tujuan tidak mungkin terwujud tanpa peran aktif karyawan meskipun alat-alat yang dimiliki perusahaan sangat lengkap tetapi jika peran aktif karyawan tidak diikutsertakan, maka alat-alat tersebut tidak ada manfaatnya bagi perusahaan. Mengatur karyawan adalah sulit dan kompleks, karena mereka mempunyai pikiran, perasaan, status, keinginan, dan latar belakang yang heterogen yang dibawa ke dalam organisasi. Karyawan tidak dapat diatur dan dikuasai sepenuhnya seperti mengatur mesin, modal, atau gedung. Manajemen Sumber Daya Manusia diperlukan agar perusahaan dapat mengembangkan, menggunakan, mengevaluasi, dan memelihara karyawan dalam jumlah (kuantitas) dan tipe (kualitas) yang tepat.

Kinerja adalah sebuah kata dalam bahasa Indonesia dari kata dasar "kerja" yang menterjemahkan kata dari bahasa asing prestasi, dapat pula berarti hasil kerja. Pengertian Kinerja dalam organisasi merupakan jawaban dari berhasil atau tidaknya tujuan organisasi yang telah ditetapkan. Para atasan atau manajer sering 
tidak memperhatikan kecuali sudah amat buruk atau segala sesuatu jadi serba salah. Terlalu sering manajer tidak mengetahui betapa buruknya kinerja telah merosot sehingga perusahaan / instansi menghadapi krisis yang serius. Kesan - kesan buruk organisasi yang mendalam berakibat dan mengabaikan tanda - tanda peringatan adanya kinerja yang merosot.

Menurut As'ad (2001), kinerja adalah keberhasilan seseorang pekerja terkait dengan keberhasilan menyelesaikan tugasnya, sehingga karyawan yang mempunyai kinerja baik bisa meningkatkan kinerja perusahaan secara keseluruhan, yang pada akhirnya membawa kesejahteraan bersama

Faktor-Faktor Yang Mempengaruhi Kinerja menurut adalah:

1. Kemampuan

2. Motivasi,

3. Dukungan yang diterima,

4. Keberadaan pekerjaan yang mereka lakukan, dan

5. Hubungan mereka dengan organisasi. Pada dasarnya perusahaan mengharapkan karyawan yang mampu, cakap, dan terampil, tetapi yang terpenting mereka mau bekerja giat dan berkeinginan untuk mencapai hasil kerja yang optimal. Kemampuan, kecakapan, dan ketrampilan karyawan tidak ada artinya bagi perusahaan, jika mereka tidak termotivasi / tidak mau bekerja keras dengan mempergunakan kemampuan, kecakapan, dan ketrampilan yang dimilikinya. Motivasi termasuk unsur yang penting, karena dengan motivasi ini diharapkan setiap individu karyawan mau bekerja keras dan antusias untuk mencapai produktivitas kerja yang tinggi. (Hasibuan, 1996). Manajer dalam memotivasi harus menyadari bahwa orang akan mau bekerja keras dengan harapan, ia akan dapat memenuhi kebutuhan dan keinginankeinginannya dari hasil pekerjaannya.

Kemampuan kerja karyawan berhubungan erat dengan motivasi dan kinerja karyawan, Moekijat (2002) menyatakan bahwa kinerja merupakan fungsi dari motivasi dengan kemampuan kerja. Kinerja karyawan akan rendah, jika kemampuan kerja tinggi dan motivasi kerja rendah atau sebaliknya, maka kinerja karyawan akan rendah pula. Kemampuan dan motivasi kerja dalam melaksanakan pekerjaan memiliki kinerja organisasi yang berorientasi kepada profit, sehingga kinerja yang baik sangat diperlukan dan berperan pada organisasi yang akan mengalami pertumbuhan lebih baik. Karyawan yang memilki kemampuan diatas rata-rata dengan pendidikan yang memadai untuk jabatannya, dan memiliki keterampilan dalam melaksanakan tugas sehari-harinya, ia akan mampu mencapai tingkat kinerja yang lebih tinggi. Oleh sebab itu penempatan karyawan harus sesuai dengan 
tingkat pendidikan, tingkat keahlian/ pengalamannya dan harus sesuai dengan tingkat keterampilannya. Selain itu, kemampuan karyawan akan mudah mencapai tingkat kinerja yang diharapkan apabila didukung oleh motivasi yang tinggi.

Dari pemaparan tersebut diatas, dapat dinyatakan bahwa untuk mewujudkan Visi PT Sang Hyang Seri (persero) KR III Malang, agar menjadi perusahaan agroindustri benih nasional berkelas dunia, maka diperlukan kinerja karyawan yang berkualitas dan mempunyai daya saing berkelas dunia. Sehingga penilaian kinerja karyawan merupakan hal yang terpenting yang harus dilakukan. Dalam penelitian ini, faktor-faktor yang mempengaruhi kinerja karyawan adalah kemampuan kerja dan motivasi kerja.

\section{METODE PENELITIAN}

\section{A. Metode Dasar}

Metode yang digunakan dalam penelitian ini adalah metode diskriptif, yaitu suatu metode dalam meneliti status suatu kelompok manusia, suatu objek, suatu kondisi, suatu sistem pemikiran, ataupun suatu peristiwa pada masa sekarang. Tujuan penelitian deskriptif adalah untuk membuat deskripsi, gambaran atau lukisan secara sistematis, faktual dan akurat mengenai fakta-fakta, sifat-sifat serta hubungan antar fenomena yang diselidiki.

\section{B. Metode Pelaksanaan Penelitian}

Metode Penelitian yang digunakan adalah metode studi kasus, yaitu penelitian tentang subjek penelitian yang berkenaan dengan suatu fase spesifik atau khas dari keseluruhan personalitas. Subyek dalam studi kasus dapat berupa individu, kelompok, lembaga, maupun masyarakat (Nazir, 1999). Penelitian studi kasus ini dilakukan di PT Sang Hyang Seri (Persero) Kantor Regional III.

\section{Metode Penentuan Tempat Penelitian}

Metode yang digunakan dalam penentuan tempat penelitian adalah purposive, penentuan lokasi/tempat penelitian secara sengaja yang didasarkan atas ciri atau sifat tertentu sesuai dengan tujuan penelitian.

Penelitian ditentukan pada PT Sang Hyang Seri (Persero) Kantor Regional III yang berkantor pusat di Kota Malang, merupakan perusahaan agroindustri perbenihan di Indonesia, yang sebagian besar daerah kerjanya di sekitar Jawa Timur dan merupakan wilayah kerja yang mendapat penilaian Baik dari hasil evaluasi di setiap tahunnya di lingkungan wilayah kerja PT. Sang Hyang Seri (persero) se Indonesia.

\section{Populasi dan Sampel}

Sebagai Populasi dari penelitian ini adalah semua karyawan bagian Produksi 
PT Sang Hyang Seri (Persero) Kantor Regional III Wilayah Jawa Timur. Pengambilan sampel dilakukan secara Sensus, artinya teknik sampling ini mengambil semua anggota populasi dari suatu kumpulan untuk dijadikan sampel.

Pada penelitian ini dilakukan di bagian Produksi pada 5 (lima) lokasi Kantor Regional III PT. Sang Hyang Seri (Persero) yang berada di wilayah Jawa Timur, yaitu di :

1. Kantor Pusat KR III Malang,

2. Kantor Cabang Jember

3. Kantor Cabang Pasuruan

4. Kantor Cabang Nganjuk

5. Kantor Satgas Pujon

Jumlah karyawan Bagian Produksi PT Sang Hyang Seri (Persero) Kantor Regional III Wilayah Jawa Timur adalah 38 orang, yang terdiri dari 22 pegawai tetap dan 16 orang pegawai kontrak.

\section{E. Metode Pengolahan Data}

1. Macam dan sumber data

a. Macam Data

1) Data Primer, merupakan data yang diperoleh dengan cara wawancara langsung dengan menggunakan daftar pertanyaan yang telah dipersiapkan pada Karyawan PT Sang Hyang Seri KR III.

2) Data Sekunder adalah data yang diperoleh dari arsip/catatan di PT Sang Hyang Seri KR III, Pustaka, dan Internet.

\section{b. Sumber Data}

Data diperoleh dari Pustaka, internet, dan Arsip Perusahaan

\section{Cara pengambilan data}

a. Kuesioner, yaitu sejumlah pernyataan tertulis yang akan dijawab responden agar peneliti memperoleh data lapangan/empiris untuk memecahkan masalah penelitian, dan menguji hipotesis yang ditetapkan.

b. Wawancara / Interview, yaitu mengumpulkan data yang didapat dari tanya jawab antara peneliti dengan responden.

c. Pengamatan, yaitu mengumpulkan data dengan cara mengamati apa yang dilakukan responden dalam kinerjanya pada lokasi penelitian.

d. Studi Pustaka, yaitu dilakukan dengan mencari data atau informasi melalui penelusuran referensi yang relevan dengan proses penelitian.

\section{F. Teknik Analisis dan Pengujian Hipotesis}

1. Teknik Analisis

a. Analisis Kualitatif

Analisis data secara kualitatif bersifat memaparkan hasil temuan secara mendalam melalui pendekatan non statistik. Analisis kualitatif ini dikumpulkan dari hasil wawancara. Dalam pelaksanaannya menggunakan kuesioner yaitu pengumpulan data 
yang menggunakan angket dengan cara mengajukan daftar pertanyaan secara tertulis kepada sampel penelitian, dengan harapan mereka akan memberikan respon atas daftar pertanyaan tersebut.

\section{b. Analisis Kuantitatif}

Analisis kuantitatif menggunakan dasar pendekatan angka, sehingga proses pemberian skala pada data mentah banyak diterapkan disini. Penerapannya yaitu dalam proses pemberian kode terhadap data kuesioner, sehingga kemudian dapat dilakukan analisis kuantitatif. Dalam praktek analisis kuantitatif yang banyak digunakan adalah analisis statistik dengan menggunakan program SPSS. Sebelum data diolah, terlebih dahulu data dianalisis dengan uji validitas dan uji reliabilitas.

Dalam penelitian ini skala yang akan digunakan adalah skala likert. Skala likert ini berhubungan dengan pernyataan sikap seseorang terhadap sesuatu (Husein,2004).

Dengan Skala Likert, maka variabel yang akan diukur dijabarkan menjadi indikator variabel. Kemudian indikator tersebut dijadikan sebagai titik tolak untuk menyusun item-item instrumen yang didapat dari pernyataan atau pertanyaan. (Istiyanto, 2004).

$\begin{array}{crr}\text { Jawaban } & \text { setiap } & \text { item } \\ \text { instrumen/indikator } & & \text { yang } \\ \text { menggunakan } & \text { Skala } & \text { Likert }\end{array}$

mempunyai gradasi dari sangat positif sampai dengan sangat negatif, yang berupa kata-kata antara lain :

$\begin{array}{lll}\text { Sangat Setuju (SS) } & \text { diberi nilai } & 5 \\ \text { Setuju (S) } & \text { diberi nilai } & 4 \\ \text { Netral (N) } & \text { diberi nilai } & 3 \\ \text { Tidak Setuju (TS) } & \text { diberi nilai } & 2 \\ \text { Sangat Tidak Setuju (STS) } & \text { diberi nilai } & 1\end{array}$

\section{Uji Instrumentasi Penelitian}

a. Uji Validitas

Uji validitas bertujuan untuk mengetahui tingkat ketepatan dan kecermatan alat ukur (instrumen / indikator) dalam melakukan fungsinya sebagai alat ukur serta mampu mengungkapkan data dengan tepat. (Suwardie,2007).

Jika peneliti menggunakan kuesioner dalam pengumpulan data, maka kuesioner yang disusun harus bisa mengukur apa yang ingin diukur oleh peneliti.

Untuk menilai data valid atau tidak maka harus semakin tinggi nilai uji validitas, maka semakin baik pernyataan yang digunakan.

Setelah kuesioner tersebut tersusun dan teruji validitasnya, dalam praktek belum tentu data yang terkumpul adalah data yang valid, maka diperlukan uji validitas yang dapat dilakukan dengan korelasi momen tangkar (product moment), 
yaitu membandingkan nilai $r$ tabel dengan $\mathrm{r}$ hitungnya (statistiknya). Jika $\mathrm{r}$ hitung lebih besar $r$ tabel maka data tersebut valid, atau dapat dinyatakan apabila koefisien korelasi $\left(\mathrm{r}_{\mathrm{xy}}\right)>0,3$ maka data tersebut Valid, dan sebaliknya .

Dengan rumus sebagai berikut :

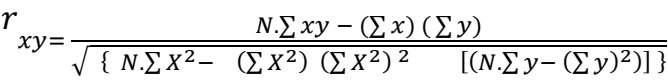

Keterangan :

r : koefisien korelasi

n : jumlah sampel

X : skor total / jawaban

Y : skor total

Tabel 1 Hasil Uji Validitas Alat Ukur Variabel Kemampuan Karyawan

\begin{tabular}{|c|l|l|c|r|r|c|}
\hline No. & \multicolumn{1}{|c|}{ Variabel } & \multicolumn{1}{|c|}{ Dimensi } & Indikator & r hitung & r tabel & Ket. \\
\hline 1 & Kemampuan & Pengetahuan & a & 0,987 & 0,271 & Valid \\
& & & b & 0,987 & 0,271 & Valid \\
\cline { 3 - 7 } & & Pengalaman & a & 0,494 & 0,271 & Valid \\
& & & $\mathrm{b}$ & 1,000 & 0,271 & Valid \\
\hline & Skill & $\mathrm{a}$ & 0,836 & 0,271 & Valid \\
& Ketrampilan & $\mathrm{b}$ & 0,774 & 0,271 & Valid \\
& & $\mathrm{c}$ & 0,828 & 0,271 & Valid \\
& & & $\mathrm{d}$ & 0,808 & 0,271 & Valid \\
\hline
\end{tabular}

Sumber : Data Primer Diolah

Tabel 2. Hasil Uji Validitas Alat Ukur Variabel Motivasi Karyawan

\begin{tabular}{|c|l|l|c|c|c|c|}
\hline No. & \multicolumn{1}{|c|}{ Variabel } & \multicolumn{1}{|c|}{ Dimensi } & Indikator & r hitung & r tabel & Ket. \\
\hline 1 & Motivasi & Kebutuhan & a & 0,675 & 0,271 & Valid \\
& & Aktualisasi Diri & b & 0,676 & 0,271 & Valid \\
& & & c & 0,774 & 0,271 & Valid \\
& & & d & 0,790 & 0,271 & Valid \\
& & & e & 0,712 & 0,271 & Valid \\
& & & f & 0,671 & 0,271 & Valid \\
& & & & & &
\end{tabular}

Sumber : Data Primer Diolah 
Tabel 3 Hasil Uji Validitas Alat Ukur Variabel Kinerja Karyawan

\begin{tabular}{|c|c|c|c|c|c|c|}
\hline No. & Variabel & Dimensi & Indikator & r hitung & $r$ tabel & Ket. \\
\hline \multirow[t]{28}{*}{3} & \multirow[t]{8}{*}{ Kinerja Karyawan } & \multirow[t]{8}{*}{ Kualitas Kerja } & $\mathrm{a}$ & 0,592 & 0,271 & Valid \\
\hline & & & $\mathrm{b}$ & 0,321 & 0,271 & Valid \\
\hline & & & $\mathrm{c}$ & 0,517 & 0,271 & Valid \\
\hline & & & d & 0,629 & 0,271 & Valid \\
\hline & & & $\mathrm{e}$ & 0,433 & 0,271 & Valid \\
\hline & & & $\mathrm{f}$ & 0,575 & 0,271 & Valid \\
\hline & & & 9 & 0,703 & 0,271 & Valid \\
\hline & & & $\mathrm{h}$ & 0,476 & 0,271 & Valid \\
\hline & & \multirow[t]{4}{*}{ Efektifitas Kerja } & $\mathrm{a}$ & 0,886 & 0,271 & Valid \\
\hline & & & $\mathrm{b}$ & 0,955 & 0,271 & Valid \\
\hline & & & $\mathrm{c}$ & 0,938 & 0,271 & Valid \\
\hline & & & d & 0,921 & 0,271 & Valid \\
\hline & & \multirow{10}{*}{$\begin{array}{l}\text { Konsistensi } \\
\text { Kerja }\end{array}$} & $\mathrm{a}$ & 0,490 & 0,271 & Valid \\
\hline & & & $\mathrm{b}$ & 0,591 & 0,271 & Valid \\
\hline & & & $\mathrm{c}$ & 0,616 & 0,271 & Valid \\
\hline & & & $d$ & 0,666 & 0,271 & Valid \\
\hline & & & $\mathrm{e}$ & 0,595 & 0,271 & Valid \\
\hline & & & $\mathrm{f}$ & 0,713 & 0,271 & Valid \\
\hline & & & $\mathrm{g}$ & 0,632 & 0,271 & Valid \\
\hline & & & $\mathrm{h}$ & 0,560 & 0,271 & Valid \\
\hline & & & $\mathrm{e}$ & 0,580 & 0,271 & Valid \\
\hline & & & $\mathrm{f}$ & 0,711 & 0,271 & Valid \\
\hline & & \multirow{6}{*}{$\begin{array}{l}\text { Kerjasama atau } \\
\text { hubungan kerja }\end{array}$} & $\mathrm{a}$ & 0,769 & 0,271 & Valid \\
\hline & & & b & 0,646 & 0,271 & Valid \\
\hline & & & $\mathrm{c}$ & 0,791 & 0,271 & Valid \\
\hline & & & $d$ & 0,668 & 0,271 & Valid \\
\hline & & & $\mathrm{e}$ & 0,781 & 0,271 & Valid \\
\hline & & & $\mathrm{f}$ & 0,611 & 0,271 & Valid \\
\hline
\end{tabular}

Sumber : Data Primer Diolah

\section{b. Uji Reliabilitas}

Reliabilitas adalah derajat ketepatan, ketelitian, atau keakuratan yang ditunjukkan oleh instrumen pengukuran.
Pengujiannya dapat dilakukan secara internal, yaitu pengujian dengan menganalisis konsistensi butir-butir yang ada. Untuk mencari reliabilitas instrumen 
dapat menggunakan teknik Cronbach (Husein, 2004).

Uji reliabilitas nienunjukkan tingkat kemantapan dan keandalan suatu alat ukur. Suatu kuesioner dikatakan reliabel jika jawaban seseorang terhadap pertanyaan stabil dari waktu ke waktu. Dalam penelitian ini, uji reliabilitas dilakukan sekali dan hasilnya dibandingkan dengan pertanyaan lain. Suatu kuesioner dikatakan reliabel jika alpha > 0,60 dengan $\mathrm{n}>30$ (Supomo, 1994).

Rumus Teknik Cronbach adalah sebagai berikut :

$$
r_{i i=\left(\frac{k}{k-1}\right)}\left[1-\frac{\sum \sigma_{i}^{2}}{\sigma_{t}^{2}}\right]
$$

Keterangan :

$\mathrm{r}_{\mathrm{ii}} \quad$ : reliabilitas instrumen

$\mathrm{k} \quad$ : banyaknya butir pertanyaan

$\sum \sigma_{b}^{2} \quad$ : jumlah varians butir

$\sigma_{t}^{2} \quad$ : varians butir

i : butir

$\mathrm{t} \quad$ : total

Dengan :

$\frac{\sum y^{2}-\left(\sum y\right)^{2} / n}{n}$

n : banyaknya responden

$\sum \mathrm{y} \quad$ : jumlah skor total

Tabel 4. Hasil Uji Validitas Alat Ukur

\begin{tabular}{|c|l|l|c|c|c|}
\hline No. & \multicolumn{1}{|c|}{ Variabel } & \multicolumn{1}{|c|}{ Dimensi } & Alpha & $\begin{array}{c}\text { Nilai } \\
\text { Batas }\end{array}$ & \multicolumn{1}{|c|}{ Ket. } \\
\hline 1 & Kemampuan & Pengetahuan & 0,970 & 0,60 & Reliabel \\
& & Pengalaman & 0,648 & 0,60 & Reliabel \\
& & Skill Ketrampilan & 0,825 & 0,60 & Reliabel \\
\hline 2 & Motivasi Kerja & Kebutuhan Aktualisasi Diri & 0,811 & 0,60 & Reliabel \\
\hline 3 & Kinerja & Kualitas Kerja & 0,635 & 0,60 & Reliabel \\
& Karyawan & Efektifitas Kerja & 0,940 & 0,60 & Reliabel \\
& & Konsistensi Kerja & 0,809 & 0,60 & Reliabel \\
& & Kerjasama atau hubungan kerja & 0,780 & 0,60 & Reliabel \\
\hline
\end{tabular}

Sumber : Data Primer Diolah.

3. Metode Analisis dan Pengujian Hipotesis

\section{a. Metode Analisis}

Metode untuk menganalisis kemampuan kerja karyawan didapatkan :

$>$ Jumlah skor terendah $: 8$

$>$ Jumlah skor tertinggi : 40

$$
\begin{aligned}
\text { Interval } & =\frac{\text { Jumlah skor tertinggi }- \text { Jumlah skor terendah }}{\text { Jumlah kriteria }} \\
& =\frac{40-8}{3}=11
\end{aligned}
$$

Kriteria kemampuan kerja :

$$
\begin{aligned}
> & \text { Skor }=29-40 \\
& (\text { Kemampuan tinggi) }
\end{aligned}
$$


$>$ Skor $=17-28$

(Kemampuan sedang)

$>$ Skor $=<17$

(Kemampuan rendah)

Metode untuk menganalisis motivasi kerja karyawan, berdasar dari tabel 1, didapatkan :

$>$ Jumlah skor terendah $\quad: 30$

$>$ Jumlah skor tertinggi $: 150$

Interval $=\underline{150-30}=40$

Kriteria Motivasi Kerja :

$>$ Skor $=110-150$

(Motivasi tinggi)

$>$ Skor $=69-109$

(Motivasi sedang)

Skor $=<69$

(motivasi rendah)

\section{b. Uji Hipotesis}

Untuk mengetahui seberapa besar pengaruh Kemampuan dan Motivasi Terhadap kinerja Karyawan, digunakan analisis regresi berganda yang dilanjutkan dengan Path Analysis.

Analisis Regresi Berganda, dinyatakan sebagai hubungan fungsional. Metode tersebut digunakan karena pada penelitian ini terdapat lebih dari satu variabel independen, sehingga menurut Algifari (1997) digunakan Analisis Regresi Berganda, sebagai berikut :

$$
Y=a+b_{1} X_{1}+b_{2} X_{2}
$$

Keterangan :

$$
\begin{aligned}
\mathrm{Y} & =\text { variabel dependent } \\
& =\text { kinerja karyawan (skor) } \\
\mathrm{X}_{1} & =\text { variabel independent } 1 \\
& =\text { kemampuan (skor) } \\
\mathrm{X}_{2} & =\text { variabel independent } 2 \\
& =\text { motivasi (skor) } \\
\mathrm{a} & =\text { intersep } \\
\mathrm{b} & =\text { koefisien regresi (skor) }
\end{aligned}
$$

Uji ketepatan statistik pada analisis regresi meliputi uji ketepatan model yang diukur melalui koefisien determinasi $\left(R^{2}\right.$ adjusted), Uji F, dan Uji t.

Koefisien Determinasi digunakan untuk menghitung besarnya peranan atau pengaruh variabel bebas terhadap variabel tergantung. Koefisien determinasi dihitung dengan mengkuadratkan hasil korelasi kemudian dikalikan dengan $100 \%\left(\mathrm{R}^{2}\right.$ x $\left.100 \%\right)$. Dalam penelitian ini, koefisien determinasi digunakan untuk mengetahui sumbangan / kontribusi variabe $X_{1}$ dan $\quad X_{2}$ secara bersama-sama terhadap variabel $Y$.

$\mathrm{R}^{2}=\frac{\mathrm{ESS}}{T S S}$

keterangan :

$\mathrm{ESS}=$ jumlah kuadrat yang dijelaskan

TSS = jumlah kuadrat total

Nilai $R^{2}$ menunjukkan persentase variasi nilai variabel dependen yang dapat dijelaskan oleh persamaan regresi yang 
dihasilkan. Kecocokan model dikatakan lebih baik jika $\mathrm{R}^{2}$ yang dihasilkan semakin mendekati angka satu. Nilai koefisien analisis regresi dijelaskan oleh parameter variabel bebas yang digunakan dalam model regresi, sedangkan sisanya dijelaskan oleh variabel-variabel lainnya diluar variabel yang diteliti.

Untuk menguji ada tidaknya pengaruh variabel bebas $(\mathrm{X} 1, \mathrm{X} 2)$ terhadap variabel tergantung $Y$, dilakukan uji $\mathrm{F}$ dan uji t.

Uji Hipotesis secara serempak (Uji F) :

Perumusan Hipotesis :

Ho : $\beta_{i}=0$

Ha : salah satu $\beta_{i} \neq 0$

Terdapat pengaruh antara vriabel $X_{1}$, $X_{2}$ secara bersama-sama terhadap variabel $Y$. Dengan $\alpha=5 \%$ dan derajat kebebasan $\mathrm{dk}=(\mathrm{k}-1) ;(\mathrm{N}-\mathrm{k})$ akan diperoleh nilai $\mathrm{F}$ tabel $=$ F $0,05 \mathrm{dk}(\mathrm{k}-1) ;(\mathrm{N}-\mathrm{k})$.

Kriteria Pengujian :

- Ho diterima jika F hit < F tabel ; artinya secara bersama-sama variabel independen tidak berpengaruh terhadap variabel dependen

- Ho ditolak jika F hit > F tabel ; artinya secara bersama-sama variabel independen berpengaruh terhadap variabel dependen

Uji Hipotesis secara parsial (Uji t)

Perumusan Hipotesis :

Ho : $\beta_{i}=0$
Ha : $\beta_{i} \neq 0, \mathrm{i}: 1$ atau 2

Uji hipotesis di dua sisi dilakukan dengan penentuan nilai $\alpha=5 \%$ dan derajat kebebasan $=\mathrm{N}-\mathrm{k}$ akan diperoleh nilai $\mathrm{t}$-tabel $=\mathrm{t} 0,05$ $\mathrm{dk}(\mathrm{N}-\mathrm{k})$.

Kriteria Pengujian :

- Ho diterima jika $\mathrm{t}$ hit $\leq \mathrm{t}$ tabel, $\mathrm{Ha}$ ditolak, artinya kemampuan dan motivasi secara parsial tidak berpengaruh terhadap kinerja karyawan

- Ho ditolak jika $\mathrm{t}$ hit $>\mathrm{t}$ tabel, $\mathrm{Ha}$ diterima berarti Kemanpuan dan Motivasi secara parsial berpengaruh terhadap kinerja karyawan

Untuk menganalisis pengaruh kemampuan dan motivasi terhadap kinerja, digunakan Path Analysis (Analisis jalur) sebagai berikut :

Menurut Sitepu (1994) dalam penelitian, seorang peneliti berusaha mengungkapkan hubungan antara gejala alami, atau usaha mengungkapkan hubungan antara variabel. Untuk menentukan besarnya pengaruh suatu variabel terhadap variabel lainnya baik itu pengaruh sifatnya langsung atau tidak langsung, dapat digunakan Analisis Jalur.

Yang mengisyaratkan hubungan kausal Y1, ..., Yk atas X1, ... Xk. Apabila setiap variabel $\mathrm{Y}$ secara unik keadaannya ditentukan atau disebabkan oleh seperangkat variabel $\mathrm{X}$, maka persamaan itu disebut persamaan struktural, modelnya 
disebut model struktural dan gambaran yang memperlihatkan struktur hubungan kausal antara variabel disebut diagram jalur atau diagram alur (path diagram).

Pada saat menggambarkan diagram jalur ada beberapa perjanjian :

a. Hubungan antar variabel digambarkan oleh anak panah yang bisa berkepala tunggal $(\rightarrow)$ atau single headed arrow, ada yang berkepala dua $(\leftrightarrow)$ atau double headed arror.

b. Panah yang berkepala satu menunjukkan pengaruh.

Jadi kalau ada 2 (dua) buah variabel $\mathrm{X}_{1}$ dan $\mathrm{X}_{2}$ dan menurut teori $\mathrm{X}_{1}$ memperngaruhi $\mathrm{X}_{2}$ maka gambarnya adalah :

$\mathrm{X}_{1} \rightarrow \mathrm{X}_{2}$

Gambar 1. Pengaruh $X_{1}$ terhadap $X_{2}$ varabel yang digambarkan pada ujung panah merupakan variabel akibat, sedangkan variabel yang pertama digambarkan disebut variabel penyebab.

c. Hubungan sebab akibat merupakan hubungan hubungan yang mengikuti hubungan asimetrik, tetapi ada kemungkinan bahwa hubungan kausal itu mengganbarkan hubungan timbal balik, jadi kalau ada variabel $\mathrm{X}_{1}$ dan $\mathrm{X}_{2}, \mathrm{X}_{1}$ bisa mempengaruhi $\mathrm{X}_{2}$ atau $\mathrm{X}_{2}$ bisa mempengaruhi $\mathrm{X}_{1}$.

gambarnya adalah :

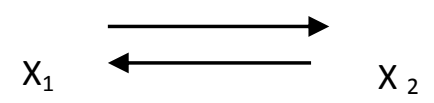

gambar 2. Hubungan timbal balik d. Bila terjadi hubungan antara dan merupakan hubungan korelatif keadaan seperti ini panahnya berkepala dua dan gambarnya adalah :

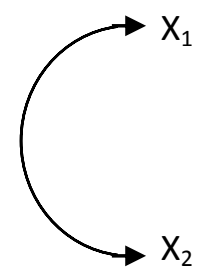

Gambar 3. Hubungan korelasi

e. Dalam dunia nyata tidak pernah seseorang bisa mengisolasi hubungan pengaruh secara murni, artinya bahwa suatu kejadian banyak sekali yang mempengaruhi, tetapi secara conceptual framwork hanya dapat digambarkan beberapa pengaruh yang bisa diamati. Variabel lainnya yang tidak bisa digambarkan beberapa pengaruh yang bisa diamati. Variabel lainnya yang tidak bisa digambarkan (tidak bisa diukur) diperlihatkan oleh suatu variabel tertentu disebut residu dan diberi simbol $\varepsilon$.

f. Membaca diagram jalur

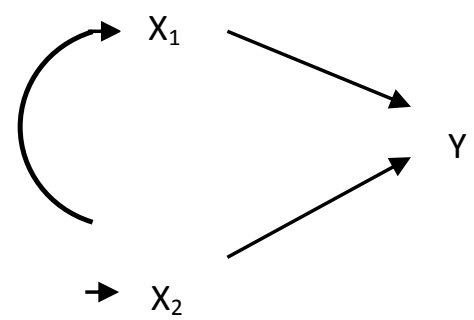

Gambar 4. Hubungan kausal antara variabel $\mathrm{X}_{1}, \mathrm{X}_{2}$ dan $\mathrm{Y}$

Akibat dari membaca pada diagram jalur, maka terdapat :

1. Pengaruh yang sifatnya langsung, artinya dari $\mathrm{Y}$ ke $\mathrm{X}_{1}$ kembali ke $\mathrm{Y}$. 
2. Pengaruh yang sifatnya tidak langsung, artinya dari $\mathrm{Y}$ ke $\mathrm{X}_{1}$ melalui $\mathrm{X}_{2}$ kembali ke $\mathrm{Y}$.

Sebuah diagram jalur merupakan sebuah struktur yang lengkap ini terdiri dari sub-sub struktur yang mengidentifikasinya melalui bentuk yang menyerupai struktur regresi. Berdasarkan sub struktur inilah peneliti menghitung koefisien-koefisien jalur dan mengambil kesimpulan secara keseluruhan nantinya.

Besarnya pengaruh dari suatu variabel penyebab ke variabel akibat disebut dengan koefisien jalur dan diberi simbol dengan $\mathrm{P}_{\text {xixj. }}$ Koefisien jalur ( path coeficient ) adalah koefisien yang tidak punya satuan, oleh karena itu secara relativ bisa sekaligus mengambil kesimpulan bahwa semakin besar koefisien jalur maka secara relatif makin besar pengaruh yang diberikan variabel itu.

Uji Hipotesis :

$$
\begin{aligned}
\text { Ho }= & \text { kemampuan dan motivasi tidak } \\
& \text { berpengaruh terhadap kinerja } \\
& \text { karyawan }\left(\mathrm{p}_{\mathrm{i}} \mathrm{y} \leq 0\right) \\
\mathrm{Ha}= & \text { kemampuan dan motivasi } \\
& \text { berpengaruh terhadap kinerja } \\
& \text { karyawan }\left(\mathrm{p}_{\mathrm{i}} \mathrm{y}>0\right)
\end{aligned}
$$
$\mathrm{Ha}=$ kemampuan dan motivasi berpengaruh terhadap kinerja karyawan $\left(\mathrm{p}_{\mathrm{i}} \mathrm{y}>0\right)$

Jika $\mathrm{p}_{\mathrm{i}} \mathrm{y} \leq 0$ : Ho diterima dan $\mathrm{Ha}$ ditolak

Jika $\mathrm{p}_{\mathrm{i}} \mathrm{y}>0$ : Ho ditolak dan $\mathrm{Ha}$ diterima.

\section{HASIL DAN PEMBAHASAN}

A. Identitas Karyawan Bagian Produksi PT. Sang Hyang Seri KR III Wilayah Jawa Timur

Responden penelitian ini adalah karyawan bagian produksi PT. Sang Hyang Seri (Persero) Kantor Regional III dengan wilayah kerja Jawa Timur, sebanyak 38 orang. Adapun identitas karyawan bagian produksi tersebut dapat dilihat pada tabel 5.1.

\begin{tabular}{|c|c|c|c|}
\hline No. & Identitas & Jumlah (orang) & Persentase $(\%)$ \\
\hline \multirow[t]{4}{*}{1} & Jenis Kelamin & & \\
\hline & Laki-laki & 36 & 94,7 \\
\hline & Perempuan & 2 & 5,3 \\
\hline & Jumlah & 38 & 100,0 \\
\hline \multirow[t]{6}{*}{2} & Umur & & \\
\hline & 20 - 30 tahun & 15 & 39,5 \\
\hline & $31-40$ tahun & 5 & 13,2 \\
\hline & 41 - 50 tahun & 13 & 34,2 \\
\hline & $>50$ tahun & 5 & 13,2 \\
\hline & Jumlah & 38 & 100,0 \\
\hline
\end{tabular}

Tabel 5 Identitas Karyawan bagian produksi PT Sang Hyang Seri (Persero) Kantor Regional III dengan wilayah kerja Jawa Timur 


\begin{tabular}{|c|c|c|c|}
\hline No. & Identitas & Jumlah (orang) & Persentase $(\%)$ \\
\hline \multirow[t]{6}{*}{3} & Masa Kerja & & \\
\hline & $<10$ tahun & 20 & 52,6 \\
\hline & $11-20$ tahun & 8 & 21,1 \\
\hline & 21 - 30 tahun & 10 & 26,3 \\
\hline & $>30$ tahun & 0 & 00,0 \\
\hline & Jumlah & 38 & 100,0 \\
\hline \multirow[t]{5}{*}{4} & Pendidikan Terakhir & & \\
\hline & SMA & 19 & 50,0 \\
\hline & Diploma & 8 & 21,0 \\
\hline & Sarjana & 11 & 29,0 \\
\hline & Jumlah & 38 & 100,0 \\
\hline
\end{tabular}

Sumber : Data Primer Diolah

Dapat diketahui bahwa jumlah karyawan di yang berada di PT. Sang Hyang Seri (Persero) Kantor Regional III sebagian besar adalah berjenis kelamin laki-laki sebesar $94,7 \%$ dan 5,3\% adalah karyawan perempuan. Hal ini dikarenakan jenis pekerjaan yang dilaksanakan di PT. Sang Hyang Seri (Persero) Kantor Regional III tergolong membutuhkan tenaga yang kuat dan emosi yang stabil dalam menyelenggarakan kegiatannya baik di lapangan maupun di kantor, dengan volume pekerjaan beraktivitas tinggi.

Sebagian besar karyawan PT. Sang Hyang Seri (Persero) Kantor Regional III sebanyak $39.5 \%$ berumur 20-30 tahun dan sebanyak $13.2 \%$ berumur lebih dari 50 tahun. Dari masa kerjanya dapat diketahui bahwa 26,3\% memiliki masa kerja antara 21 sampai 30 tahun. Pendidikan terakhir karyawan sebagian besar adalah SMA sebesar $50 \%$ atau sejumlah 19 orang.

\section{B. Analisis Kemampuan Kerja} Karyawan Bagian Produksi PT. Sang Hyang Seri (Persero) Kantor Regional III.

\section{Pengetahuan Karyawan}

Pengetahuan karyawan dapat diperoleh melalui pendidikan formal maupun non formal. Sedangkan pengetahuan yang berkaitan dengan bidang pekerjaannya dapat dibedakan antara pengetahuan teknis dan pengetahuan umum.

Adapun rata-rata skor pengetahuan karyawan Bagian Produksi di PT. Sang Hyang Seri (Persero) KR III dapat dilihat pada tabel 6 . 
Tabel 6 Rata-rata Skor Pengetahuan Karyawan Bagian produksi di PT. Sang Hyang Seri (Persero) Kantor Regional III Tahun 2010

\begin{tabular}{|c|l|c|c|c|}
\hline \multirow{2}{*}{ No. } & \multicolumn{2}{|c|}{ Indikator } & \multicolumn{3}{c|}{ Skor } \\
\cline { 3 - 5 } & & Rata-rata & Maksimal & $\%$ \\
\hline 1 & Pengetahuan seputar pekerjaan & 4,45 & 5 & 88,95 \\
2 & Wawasan dari pihak luar & 4,47 & 5 & 89,47 \\
\hline & Jumlah & 8,92 & 10 & \\
\hline & Rata-rata & 4,46 & 5 & 89,21 \\
\hline
\end{tabular}

\section{Sumber : Data Primer Diolah}

Tabel 5.2 menunjukkan bahwa ratarata skor pengetahuan karyawan sebagian besar adalah wawasan dari pihak luar yaitu rata-rata skor 4,47 atau $89,47 \%$.

\section{Pengalaman Karyawan}

Dari perhitungan rata-rata skor pengalaman karyawan dapat dilihat pada Tabel 7. berikut ini.

Tabel 7 Rata-rata Skor Pengalaman Karyawan Bagian produksi di PT. Sang Hyang Seri (Persero) Kantor Regional III Tahun 2010

\begin{tabular}{|c|l|c|c|c|}
\hline \multirow{2}{*}{ No. } & \multicolumn{1}{|c|}{ Indikator } & \multicolumn{3}{|c|}{ Skor } \\
\cline { 3 - 5 } & & $\begin{array}{c}\text { Rata- } \\
\text { rata }\end{array}$ & Maksimal & $\%$ \\
\hline 1 & Lama bekerja di PT SHS & 3,71 & 5 & 74,21 \\
2 & Macam pekerjaan yang dulu pernah dilakukan & 3,63 & 5 & 72,63 \\
\hline & Jumlah & 7,34 & 10 & \\
\hline & Rata-rata & 3,67 & 5 & 73,42 \\
\hline
\end{tabular}

Sumber : Data Primer Diolah

Pada Tabel 7. dapat dilihat bahwa rata-rata skor teringgi adalah pada indikator Lama bekerja di PT. Sang Hyang Seri daripada macam pekerjaan yang pernah dilakukan yaitu sebesar 3,71 atau $74,21 \%$.

\section{Skill/ Ketrampilan Karyawan}

Perhitungan rata-rata skor skill/ Ketrampilan karyawan dapat dilihat pada Tabel 8. 
Tabel 8 Rata-rata Skor Skill/ Ketrampilan Karyawan Bagian produksi di PT. Sang Hyang Seri (Persero) Kantor Regional III Tahun 2010

\begin{tabular}{|c|l|c|c|c|}
\hline \multirow{2}{*}{ No. } & \multicolumn{1}{|c|}{ Indikator } & \multicolumn{3}{|c|}{ Skor } \\
\cline { 3 - 5 } & & $\begin{array}{c}\text { Rata- } \\
\text { rata }\end{array}$ & Maksimal & $\%$ \\
\hline 1 & Kerapian dalam pekerjaan & 3,34 & 5 & 66,84 \\
2 & Mengerjakan skala prioritas & 3,47 & 5 & 69,47 \\
3 & Mengerjakan tepat waktu & 3,50 & 5 & 70,00 \\
4 & Pengerjaan pekerjaan secara cepat & 3,37 & 5 & 67,37 \\
\hline & Jumlah & 13,68 & 20 & \\
\hline & Rata-rata & 3,42 & 5 & 68,42 \\
\hline
\end{tabular}

Sumber : Data Primer Diolah

Dapat dilihat bahwa skill/ ketrampilan karyawan Bidang Produksi di PT. Sang Hyang Seri Kantor Regional III wilayah Jawa Timur yang memiliki nilai tinggi adalah pada pelaksanaan pekerjaan yang tepat waktu yaitu rata-rata sebesar
3,50 atau 70\%. Sedangkan rata-rata terendah adalah 3,34 atau $66,84 \%$, yaitu pada indikator kerapian dalam pekerjaan.

Hasil Penggabungan rata-rata skor dapat dilihat sebagai berikut :

Tabel 9 Rata-rata Skor Kemampuan Karyawan Bagian produksi di PT. Sang Hyang Seri (Persero) Kantor Regional III Tahun 2015

\begin{tabular}{|c|l|c|c|c|}
\hline \multirow{2}{*}{ No. } & \multicolumn{2}{|c|}{ Dimensi } & \multicolumn{3}{c|}{ Skor } \\
\cline { 3 - 5 } & & $\begin{array}{c}\text { Rata- } \\
\text { rata }\end{array}$ & Maksimal & $\%$ \\
\hline 1 & Pengetahuan & 4,46 & 5 & 89,21 \\
2 & Pengalaman & 3,67 & 5 & 73,42 \\
3 & Skill/ Ketrampilan & 3,42 & 5 & 68,42 \\
\hline & Jumlah & 11,80 & 15 & \\
\hline & Rata-rata & 3,93 & 5 & 78,68 \\
\hline
\end{tabular}

Sumber : Data Primer Diolah

Dilihat pada tabel 9. kemampuan karyawan pada PT Sang Hyang Seri (Persero) KR III termasuk kategori tinggi dengan persentase $78,68 \%$

\section{Analisis Motivasi Kerja Karyawan Bagian Produksi PT. Sang Hyang Seri (Persero) Kantor Regional III.}

Motivasi karyawan di PT. Sang
Hyang Seri sangat penting, yang selalu dibutuhkan karyawan dalam mendorong pelaksanaan pekerjaan. Dengan motivasi yang tinggi seorang karyawan akan bersemangat menyelesaikan pekerjaan dengan baik dan benar.

Motivasi karyawan dapat diukur 
dengan dimensi kebutuhan Aktualisasi

Diri aktualisasi diri seperti pada tabel rata-rata skor dibawah ini.

Perhitungan rata-rata skor kebutuhan

Tabel 10 Rata-rata Skor Kebutuhan Aktualisasi Diri Karyawan Bagian produksi di PT. Sang Hyang Seri (Persero) Kantor Regional III Tahun 2015

\begin{tabular}{|c|l|c|c|c|}
\hline \multirow{2}{*}{ No. } & \multicolumn{1}{|c|}{ Indikator } & \multicolumn{3}{|c|}{ Skor } \\
\cline { 3 - 5 } & & $\begin{array}{c}\text { Rata- } \\
\text { rata }\end{array}$ & Maksimal & $\%$ \\
\hline 1 & Pelatihan bergiliran & 4,13 & 5 & 82,63 \\
3 & Kesempatan mengembangkan diri & 4,08 & 5 & 81,58 \\
4 & Pengembangan potensi & 4,05 & 5 & 81,05 \\
5 & Kesesuaian pekerjaan & 3,95 & 5 & 78,95 \\
6 & Pendidikan di segala bidang & 3,95 & 5 & 78,95 \\
\hline & Jumlah & 4,21 & 5 & 84,21 \\
\hline & Rata-rata & 24,37 & 30 & \\
\hline
\end{tabular}

Sumber : Data Primer Diolah

Dari Tabel 10. dapat dilihat bahwa pada indikator kesempatan mengikuti kursus memiliki nilai yang tertinggi yaitu 4,21 atau $84,21 \%$. Dan nilai rata-rata skor terendah yaitu 3,95 atau $78,95 \%$ adalah pada indikator kesesuaian pekerjaan dan pendidikan disegala bidang.

Dari data diatas maka dapat dilihat bahwa motivasi karyawan PT Sang Hyang Seri (Persero) KR III wilayah Jawa Timur dapat dikategorikan tinggi dengan persentase $81.23 \%$

D. Analisis Kinerja Karyawan Bagian Produksi PT. Sang Hyang Seri (Persero) Kantor Regional III

\section{Kualitas Kerja Karyawan}

Hasil pencatatan data primer kualitas karyawan Bagian Produksi di PT. Sang Hyang Seri maka diperoleh data sebagai berikut :

Tabel 11 Rata-rata Skor Kualitas Kerja Karyawan Bagian produksi di PT. Sang Hyang Seri (Persero) Kantor Regional III Tahun 2015

\begin{tabular}{|c|l|c|c|c|}
\hline \multirow{2}{*}{ No. } & \multicolumn{1}{|c|}{ Indikator } & \multicolumn{3}{|c|}{ Skor } \\
\cline { 3 - 5 } & $\begin{array}{c}\text { Rata- } \\
\text { rata }\end{array}$ & Maksimal & $\%$ \\
\hline 1 & Target Tahunan & 4,47 & 5 & 89,47 \\
2 & Rencana kerja tanunan & 3,89 & 5 & 77,89 \\
\hline
\end{tabular}




\begin{tabular}{|c|l|c|c|c|}
\hline \multirow{2}{*}{ No. } & \multicolumn{1}{|c|}{ Indikator } & \multicolumn{3}{|c|}{ Skor } \\
\cline { 3 - 5 } & & $\begin{array}{c}\text { Rata- } \\
\text { rata }\end{array}$ & Maksimal & $\%$ \\
\hline 3 & Ketepatan waktu kerja & 4,21 & 5 & 84,21 \\
4 & Pemanfaatan tugas harian & 3,97 & 5 & 79,47 \\
5 & Mentaati pimpinan & 4,45 & 5 & 88,95 \\
6 & Memberikan arahan pada rekan baru & 4,18 & 5 & 83,68 \\
7 & Pemahaman tugas dan wewenang & 4,18 & 5 & 83,68 \\
8 & Melaksanakan tugas dan wewenang & 4,39 & 5 & 87,89 \\
\hline & Jumlah & 33,76 & 40 & \\
\hline & Rata-rata & 4,22 & 5 & 84,41 \\
\hline
\end{tabular}

Sumber : Data Primer Diolah

Rata-rata skor tertinggi pada Tabel

5.7 adalah pada indikator target tahunan yaitu 4,47 atau $89,47 \%$ dan nilai rata-rata skor terendah adalah 3,89 atau 77,895 pada indikator recana kerja tahunan.

\section{Efektivitas Karyawan}

Adapaun data efektivitas karyawan Bagian Produksi PT. Sang Hyang Seri dapat dilihat pada Tabel 5.8. berikut ini,

Tabel 16 Rata-rata Skor Efektivitas Karyawan Bagian produksi di PT. Sang Hyang Seri (Persero) Kantor Regional III Tahun 2015

\begin{tabular}{|c|l|c|c|c|}
\hline \multirow{2}{*}{ No. } & \multicolumn{1}{|c|}{ Indikator } & \multicolumn{3}{|c|}{ Skor } \\
\cline { 3 - 5 } & & $\begin{array}{c}\text { Rata- } \\
\text { rata }\end{array}$ & Maksimal & $\%$ \\
\hline 1 & Kreatifitas kerja & 3,26 & 5 & 65,26 \\
2 & Ketepatan penyelesaian kerja & 3,26 & 5 & 65,26 \\
3 & Ketertarikan pada pekerjaan & 3,21 & 5 & 64,21 \\
4 & Variasi pekerjaan & 3,34 & 5 & 66,84 \\
\hline & Jumlah & 13,08 & 20 & \\
\hline & Rata-rata & 3,27 & 5 & 65,39 \\
\hline
\end{tabular}

Sumber : Data Primer Diolah

Rata-rata skor tertinggi adalah 3,34 atau $66,39 \%$ pada indikator variasi pekerjaan dan nilai rat-rata terendah pada indikator ketertarikan pada pekerjaan yaitu sebesar 3,21 atau 64,21\%.

\section{Konsistensi Karyawan}

Adapun perhitungan rata-rata skor konsistensi karyawan di PT. Sang Hyang Seri Bagian Produksi dapat dilihat pada Tabel 17. berikut ini. 
Tabel 17. Rata-rata Skor Konsistensi Karyawan Bagian produksi di PT. Sang Hyang Seri (Persero) Kantor Regional III Tahun 2015

\begin{tabular}{|c|l|c|c|c|}
\hline \multirow{2}{*}{ No. Indikator } & \multicolumn{3}{|c|}{ Skor } \\
\cline { 3 - 5 } & & $\begin{array}{c}\text { Rata- } \\
\text { rata }\end{array}$ & Maksimal & $\%$ \\
\hline 1 & Penerapan ilmu teknologi & 3,97 & 5 & 79,47 \\
2 & Study banding penangkaran & 4,32 & 5 & 86,32 \\
3 & Study banding dari perusahaan & 4,26 & 5 & 85,26 \\
4 & Menjaga kesehatan untuk kerja & 4,39 & 5 & 87,89 \\
5 & Menjaga hubungan kerja & 4,26 & 5 & 85,26 \\
6 & Mengikuti standar operasional & 4,32 & 5 & 86,32 \\
7 & Instruksi pimpinan & 4,42 & 5 & 88,42 \\
8 & Petunjuk pimpinan dan peraturan & 4,18 & 5 & 83,68 \\
9 & Kebebasan berinisiatif & 4,21 & 5 & 84,21 \\
10 & Peluang berkarya & 4,34 & 5 & 86,84 \\
\hline & Jumlah & 42,68 & 50 & \\
\hline & Rata-rata & 4,27 & 5 & $85, \mathrm{~s} 37$ \\
\hline
\end{tabular}

Sumber : Data Primer Diolah

Dari Tabel 5.9. menunjukkan ratarata skor tertinggi adalah 4,42 atau $88,42 \%$ yaitu pada indikator nstruksi pimpinan dan rata-rat skor terndah dengan rata-rata skor sebesar 3,97 atau 79,47 yaitu pada indikator penerapan ilmu teknologi.

\section{Kerjasama Karyawan}

Kerjasama karyawan Bagian Produksi di PT. Sang Hyang Seri mempunyai rata-rata skor rata-rata seperti yang terlihat pada tabel 5.10.

Tabel 18. Rata-rata Skor Kerjasama Karyawan Bagian produksi di PT. Sang Hyang Seri (Persero) Kantor Regional III Tahun 2015

\begin{tabular}{|c|l|c|c|c|}
\hline \multirow{2}{*}{ No. Indikator } & \multicolumn{3}{|c|}{ Skor } \\
\cline { 3 - 5 } & & $\begin{array}{c}\text { Rata- } \\
\text { rata }\end{array}$ & Maksimal & $\%$ \\
\hline 1 & Mengutamakan kerjasama & 3,97 & 5 & 79,47 \\
2 & Pembentukan tim work & 3,71 & 5 & 74,21 \\
3 & Mebina hubungan baik dengan karyawan & 3,63 & 5 & 72,63 \\
4 & Saling bantu pekerjaan & 3,58 & 5 & 71,58 \\
5 & menyelesaikan pekerjaan dengan cepat & 3,34 & 5 & 66,84 \\
6 & Lembur kantor & 3,53 & 5 & 70,53 \\
\hline & Jumlah & 21,76 & 30 & \\
\hline & Rata-rata & 3,63 & 5 & 72,54 \\
\hline
\end{tabular}

Sumber : Data Primer Diolah 
Rata-rata skor yang paling besar ada pada indikator mengutamakan kerjsama antar karyawan yaitu sebesar 3,97 atau $79,47 \%$. Sedangkan rata-rata skor yang paling rendah ada pada dimensi jati diri tugas yaitu sebesar 3,85 atau $77 \%$.

Hasil Penggabungan rata-rata skor adalah sebagai berikut :

Tabel 19 Rata-rata Skor Kinerja Karyawan Bagian produksi di PT. Sang Hyang Seri (Persero) Kantor Regional III Tahun 2015

\begin{tabular}{|c|l|c|c|c|}
\hline \multirow{2}{*}{ No. } & \multicolumn{2}{|c|}{ Dimensi } & \multicolumn{3}{c|}{ Skor } \\
\cline { 3 - 5 } & & $\begin{array}{c}\text { Rata- } \\
\text { rata }\end{array}$ & Maksimal & $\%$ \\
\hline 1 & Kualitas Kerja & 4,22 & 5 & 84,41 \\
2 & Efektivitas Kerja & 3,27 & 5 & 65,39 \\
3 & Konsistensi Kerja & 4,27 & 5 & 85,37 \\
4 & Kerjasama / Hubungan Kerja & 3,63 & 5 & 72,54 \\
\hline & Jumlah & 15,39 & 20 & \\
\hline & Rata-rata & 3,85 & 5 & 76,93 \\
\hline
\end{tabular}

Sumber : Data Primer Diolah

Pada Tabel 19. dapat dinyatakan

motivasi kerja berpengaruh positif bahwa kinerja karyawan PT Sang Hyang terhadap kinerja karyawan di PT Sang Seri (Persero) KR III dapat dikatakan Hyang Seri (persero) Kantor Regional III tinggi dengan persentase $76,93 \%$.

Malang. Untuk menjawab dugaan tersebut

\section{E. Pengujian Hipotesis}

Hipotesis dalam penelitian ini adalah dugaan bahwa kemampuan kerja dan diatas maka digunakan analisis jalur. Adapun hasil analisis regresi linier berganda dapat dilihat pada Tabel 5.12. berikut ini.

Tabel 20 Hasil Analisis Regresi Linier Berganda.

\begin{tabular}{|l|l|r|r|r|r|r|}
\hline \multirow{2}{*}{\multicolumn{2}{|c|}{ Model }} & \multicolumn{2}{|c|}{$\begin{array}{c}\text { Unstandardized } \\
\text { Coefficients }\end{array}$} & $\begin{array}{c}\text { Standardized } \\
\text { Coefficients }\end{array}$ & \multirow{2}{*}{$\mathrm{t}$} & \multirow{2}{*}{ Sig. } \\
\cline { 3 - 7 } & \multicolumn{1}{|c|}{ B } & Std. Error & \multicolumn{1}{c|}{ Beta } & & \\
\hline 1 & (Constant) & 37.785 & 9.350 & & 4.041 & .000 \\
& Kemampuan & 1.104 & .255 & .438 & 4.334 & .000 \\
& Motivasi & 1.660 & .274 & .613 & 6.064 & .000 \\
\hline
\end{tabular}

Sumber : Data Primer Diolah.

Dari Tabel 20. dapat dilihat bahwa kemampuan dan motivasi karyawan Bagian Produksi PT. Sang Hyang Seri KR
III berpengaruh signifikan terhadap kinerja bagian Produksi PT. Sang Hyang Seri. Hal ini dapat dilihat pada nilai signifikansi 
kemampuan sebesar 0,000 dan nilai signifikansi motivasi sebesar 0,000. Dari hasil analisis regresi tersebut maka untuk analisis selanjutnya adalah menggunakan analisis jalur.

\section{F. Analisis Pengaruh Kemampuan dan Motivasi Terhadap Kinerja Karyawan Bagian Produksi PT. Sang Hyang Seri (Persero) Kantor Regional III}

Analisis jalur (Path Anaysis) digunakan untuk mengetahui hubungan antar variabel penelitian. Analisis jalur merupakan pengembangan dari analisis regresi berganda.
Dari analisis regresi pada Tabel 20. terlihat bahwa variabel yang berpengaruh nyata terhadap kinerja karyawan Bagian Produksi PT. Sang Hyang Seri adalah variabel kemampuan dan motivasi. Untuk mengetahui besarnya masing-masing variabel independen dalam mempengaruhi variabel dependen dilakukan analisis jalur.

Analisis Jalur juga digunakan unutk mengetahui pengaruh langsung $\left(\mathrm{Y} \leftarrow \mathrm{X}_{1} \rightarrow \mathrm{Y}\right.$ dan $\left.\mathrm{Y} \leftarrow \mathrm{X}_{2} \rightarrow \mathrm{Y}\right)$, dan pengaruh tidak langsung

$\left(\mathrm{Y} \leftarrow \mathrm{X}_{1} \Omega \mathrm{X}_{2} \rightarrow \mathrm{Y}\right)$. Berdasarkan analisis tersebut diperoleh hasil pengaruh langsung seperti pada tabel 5.13.

Tabel 21 Hasil Analisis Jalur Kemampuan $\left(\mathrm{X}_{1}\right)$ dan Motivasi $\left(\mathrm{X}_{2}\right)$ terhadap kinerja Karyawan (Y)

\begin{tabular}{|l|c|c|c|}
\hline \multicolumn{1}{|c|}{ Variabel } & Koefisien $(\beta)$ & Tgkt Sig. & Ket. \\
\hline $\mathrm{X}_{1} \rightarrow \mathrm{Y}\left(\mathrm{P}_{\mathrm{yx} 1}\right)$ & 0.438 & 0.000 & signifikan \\
\hline $\mathrm{X}_{2} \rightarrow \mathrm{Y}\left(\mathrm{P}_{\mathrm{yx} 2}\right)$ & 0.613 & 0.000 & signifikan \\
\hline & & & \\
\hline
\end{tabular}

Koefisien jalur dihitung dengan membuat persamaan struktural : Persamaan Struktur :

$\mathrm{Y}=\mathrm{P}_{\mathrm{y} 1 \mathrm{x} 1} \mathrm{X}_{1}+\mathrm{P}_{\mathrm{y} 2 \mathrm{x} 2} \mathrm{X}_{2}+\mathrm{e}_{1}$

$\mathrm{Y}=0,438 \mathrm{X}_{1}+0,613 \mathrm{X}_{2}+\mathrm{e}_{2}$

Keterangan :

$\mathrm{Y}=$ Kinerja Karyawan

$\mathrm{P}=$ Koefisien Jalur

$\mathrm{X}_{1}=$ Kemampuan

$\mathrm{X}_{2}=$ Motivasi

e : error term, nilai kesalahan observasi

diasumsikan nol.
Dari Persamaan struktur ini dapat dibuat persamaan sub struktur .

Persamaan Sub Struktur pertama :

$\mathrm{Y}=\mathrm{P}_{\mathrm{y} 1 \mathrm{x} 1} \mathrm{X}_{1}+\mathrm{e}_{1}$

Persamaan sub Struktur ke dua :

$\mathrm{Y}=\mathrm{P}_{\mathrm{y} 2 \times 2} \mathrm{X}_{2}+\mathrm{e}_{1}$

Keterangan :

$\mathrm{Y}=$ Kinerja Karyawan

$\mathrm{P}=$ Koefisien Jalur

$\mathrm{X}_{1}=$ Kemampuan

$\mathrm{X}_{2}=$ Motivasi

e : error term, nilai kesalahan observasi 
diasumsikan nol.

Pengaruh langsung (Direct Effect) dan Pengaruh Tidak langsung (Indirect Effect)

\section{Pengaruh Langsung}

a. Pengaruh Langsung Kemampuan Karyawan

Untuk mengetahui apakah variabel Kepuasan Karyawan $\left(\mathrm{X}_{1}\right)$ berpengaruh secara langsung terhadap Kinerja Karyawan (Y), dengan menggunakan standradized coefficient (koefisien beta) maka diperoleh hasil sebagai berikut :

$\mathrm{Y} \leftarrow \mathrm{X}_{1} \rightarrow \mathrm{Y}=\mathrm{P}_{\mathrm{y} 1 \mathrm{x} 1} \mathrm{x} \mathrm{P}_{\mathrm{y} 1 \mathrm{x} 1}=0,438 \mathrm{x}$ $0,438=0,1918$

b. Pengaruh Langsung Motivasi Karyawan

Untuk mengetahui apakah variabel Motivasi Karyawan $\left(\mathrm{X}_{2}\right)$ berpengaruh secara langsung terhadap Kinerja Karyawan (Y), dengan menggunakan standradized coefficient (koefisien beta) maka diperoleh hasil sebagai berikut :

$\mathrm{Y} \leftarrow \mathrm{X}_{2} \rightarrow \mathrm{Y}=\mathrm{P}_{\mathrm{y} 2 \mathrm{x} 2} \mathrm{x} \mathrm{P}_{\mathrm{y} 2 \mathrm{x} 2}=0,613 \mathrm{x}$ $0,613=0,3758$

Berdasarkan hasil di atas maka dapat diketahui Kemampuan Karyawan $\left(\mathrm{X}_{1}\right)$ berpengaruh secara langsung terhadap Kinerja Karyawan (Y) sebesar 0,0961, dengan tingkat signifikansi 0,004 ( $\mathrm{p}<$
0,05) , dan Motivasi Karyawan $\left(\mathrm{X}_{2}\right)$ berpengaruh secara langsung terhadap Kinerja Karyawan (Y) sebesar 0,440 dengan tingkat signifikansi $0,000(\mathrm{p}<$ $0,05)$.

2. Pengaruh Tidak Langsung ( Indirect Effect)

Untuk mengetahui variabel kemampuan (X1) berpengaruh secara tidak langsung terhadap Kinerja Karyawan (Y) melalui Motivasi (X2) dengan menggunakan standardized coefficient (koefisien Beta) maka diperoleh hasil sebagai berikut :

$\mathrm{Y} \leftarrow \mathrm{X}_{1} \Omega \mathrm{X}_{2} \rightarrow \mathrm{Y}==\mathrm{p}_{1 \mathrm{y}} \mathrm{x}_{12} \mathrm{x}_{2 \mathrm{y}}=$ $0,438 \times 0,681 \times 0,613=0,1667$

Berdasarkan hasil di atas maka dapat diketahui Kemampuan Karyawan (X1) berpengaruh secara tidak langsung terhadap Kinerja Karyawan (Y) melalui Motivasi Karyawan sebesar 0,1828. Artinya Kemampuan Karyawan dan Motivasi Karyawan berpengaruh secara tidak langsung terhadap Kinerja karyawan sebesar 0,1828 dengan tingkat signifikan masing-masing kurang dari 0,05 ( $\mathrm{p}<$ $0,05)$.

Hasil Perhitungan di atas dapat digambarkan dalam gambar 5.1. di bawah ini. 


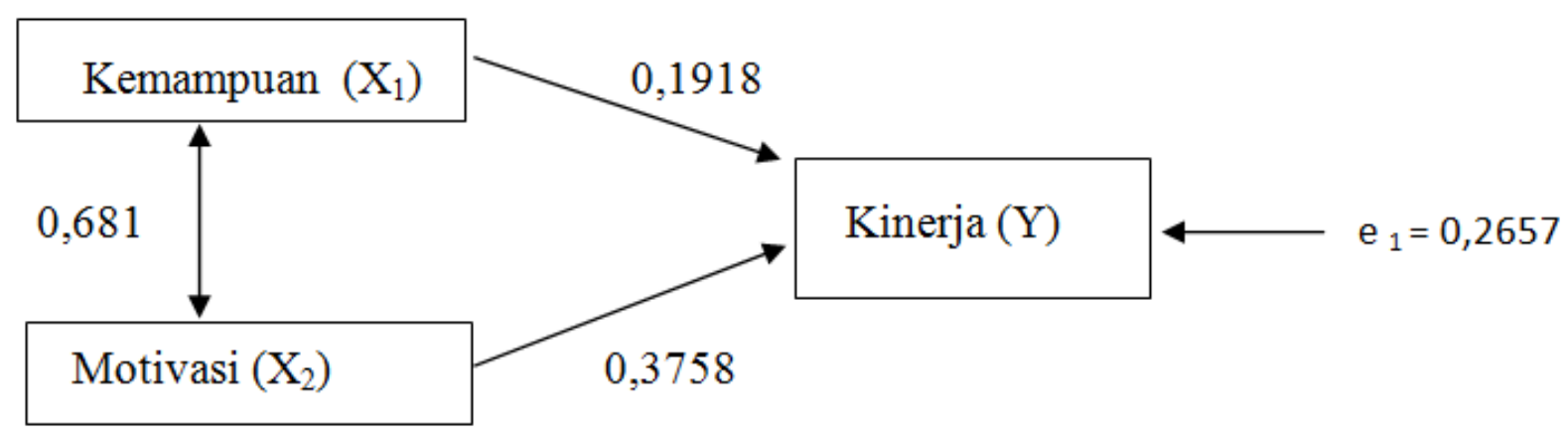

Gambar 5. Diagram jalur Kemampuan Karyawan $\left(\mathrm{X}_{1}\right)$ dan Motivasi Karyawan $\left(\mathrm{X}_{2}\right)$ terhadap Kinerja Karyawan (Y).

Untuk mengetahui pengaruh langsung tabel berikut ini :

dan tidak langsung dapat dijelaskan pada

Tabel 22. Pengaruh Langsung (direct effect/DE) dan Tidak langsung (indirect effect/IE) Kemampuan $\left(\mathrm{X}_{1}\right)$ dan Motivasi $\left(\mathrm{X}_{2}\right)$ terhadap Kinerja Karyawan $(\mathrm{Y})$

\begin{tabular}{|c|c|c|c|c|}
\hline \multirow{2}{*}{ No. } & \multirow{2}{*}{ variabel } & \multicolumn{2}{|c|}{ Koefisien Jalur } & \multirow{2}{*}{ Efek Total } \\
\cline { 3 - 5 } & & $\begin{array}{c}\text { Pengaruh } \\
\text { langsung }\end{array}$ & $\begin{array}{c}\text { Pengaruh Tidak } \\
\text { langsung }\end{array}$ & \\
\hline 1. & $\mathrm{Y} \leftarrow \mathrm{X}_{1} \rightarrow \mathrm{Y}$ & 0,1918 & & 0,1918 \\
\hline 2. & $\mathrm{Y} \leftarrow \mathrm{X}_{2} \rightarrow \mathrm{Y}$ & 0,3758 & & 0,3758 \\
\hline 3. & $\mathrm{Y} \leftarrow \mathrm{X}_{1} \Omega \mathrm{X}_{2} \rightarrow \mathrm{Y}$ & & 0,1667 & 0,1667 \\
\hline & Efek Total & 0,5676 & 0,1667 & 0,7343 \\
\hline
\end{tabular}

Keterangan : Efek Total adalah Total Pengaruh langsung dan Tidak langsung.

Berdasarkan hasil analisis maka dapat diketahui bahwa :

1. Kemampuan Karyawan $\left(\mathrm{X}_{1}\right)$ berpengaruh langsung terhadap Kinerja Karyawan (Y) diperoleh total koefisien jalur sebesar 0,1981 atau $19,18 \%$ dengan tingkat signifikansi $\left(\mathrm{Y} \leftarrow \mathrm{X}_{1}\right.$ $\rightarrow \mathrm{Y})$ sebesar 0,004 $(\mathrm{p}<0,05)$

2. Motivasi Karyawan $\left(\mathrm{X}_{2}\right)$ berpengaruh langsung terhadap Kinerja Karyawan (Y) diperoleh total koefisien jalur sebesar 0,3758 atau $37,58 \%$ dengan tingkat signifikansi sebesar 0,000 (p < $0,05)$
3. Kemampuan Karyawan $\left(\mathrm{X}_{1}\right)$ berpengaruh secara tidak langsung terhadap Kinerja Karyawan (Y) melalui Motivasi Karyawan $\left(\mathrm{X}_{2}\right)$, diperoleh total koefisien jalur sebesar 0,1667 atau $16,67 \%$ dengan tingkat signifikansi

$\left(\mathrm{Y} \leftarrow \mathrm{X}_{1} \Omega \mathrm{X}_{2} \rightarrow \mathrm{Y}\right)$ sebesar $0,000(\mathrm{p}$ $<0,05)$.

Berdasarkan analisis mengenai total koefisien pengaruh langsung (direct effect) dan tidak langsung (indirect effect) dapat diketahui bahwa :

4. Yang paling dominan mempengaruhi 
Kinerja Karyawan secara langsung di bagian Produksi PT Sang Hyang Seri (Persero) KR III adalah Motivasi Karyawan dengan koefisien jalur sebesar 0,3758 .

5. Besarnya pengaruh langsung dan tidak langsung adalah 0,7343 sehingga dapat dinyatakan bahwa kemampuan dan motivasi mempengaruhi kinerja karyawan sebesar 73,43\% sedangkan $26,57 \%$ dipengaruhi oleh variabel lain.

\section{PEMBAHASAN}

Dalam pelaksanaan tugas pokok dan fungsi di PT. Sang Hyang Seri (Persero) Kantor Regionnal III Wilayah Jawa Timur khususnya Bagian Produksi akan sangat tergantung dari kinerja para karyawan. Tinggi rendahnya kinerja karyawan ini sangat dipengaruhi oleh tingkat kemampuan dan motivasi, semakin tinggi kemampuan dan motivasi maka kinerja karyawan semakin tinggi dan sebaliknya semakin merasa rendah kemampuan dan motivasi maka kinerja karyawan semakin rendah.

Ada beberapa faktor yang dapat mempengaruhi kinerja karyawan. Dalam penelitian ini, faktor yang mempengaruhi kinerja karyawan adalah kemampuan dan motivasi kerja karyawan. Berdasarkan hasil pengujian hipotesis diperoleh hasil bahwa kemampuan dan motivasi kerja memiliki pengaruh yang positif dan signifikan terhadap kinerja karyawan Bagian Produksi PT. Sang Hyang Seri KR III Wilayah Jawa Timur baik secara bersama-sama maupun secara parsial (pvalue $<0,05)$. Hasil ini menunjukkan hipotesis penelitian ini dapat diterima yaitu kinerja karyawan dipengaruhi oleh kemampuan dan motivasi karyawan, dengan besarnya pengaruh adalah $73,43 \%$. Pengaruh yang lainnya yaitu sebesar $26,57 \%$ dipengaruhi oleh faktor lain selain kemampuan dan motivasi kerja, misalnya faktor harapan yaitu kesenjangan antara harapan karyawan dengan apa yang diperoleh.

Besarnya skor rata-rata kemampuan karyawan bagian produksi dapat dikategorikan tinggi. Untuk memdukung kemampuan, skill/ketrampilan para karyawan masih perlu ditingkatkan, antara lain dengan lebih mengintensifkan kegiatan pendidikan dan pelatihan.

Dari analisis kemampuan karyawan rata-rata skor tertinggi adalah kemampuan pada dimensi pengetahuan karyawan. Hal ini terlihat dari persentase skor penilaian responden yaitu sebesar $89,21 \%$ dengan rata-rata skor sebesar 4,46. Indikator pengetahuan karyawan yang paling menonjol adalah pada wawasan karyawan yang diperoleh dari luar atau lapangan yaitu sebesar $89,47 \%$ dengan rata-rata skor 4,47. Data ini menunjukkan secara umum bahwa responden cenderung sangat setuju 
bahwa karyawan bagian Produksi di PT. Sang Hyang Seri KR III memiliki pengetahuan dan wawasan yang tinggi dalam pelaksanaan pekerjaan di lapangan dalam menjapai tujuannya.

Sementara indikator yang paling rendah pada kemampuan karyawan adalah kerapian dalam pekerjaan dengan persentase sebesar $66,84 \%$ dan rata-rata skor 3,34. Data ini menunjukkan bahwa secara umum karyawan bagian Produksi PT. Sang Hyang Seri KR III yang merupakan perusahaan yang bergerak di sektor pertanian, pada pelaksanaan proses produksi selalu berhubungan dengan lapangan pertanian, tentu tidak akan sama situasi dan kondisinya dengan pekerjaan yang lebih dominan pada bidang administrasi perkantoran. Sehingga dalam proses pelaksanaan produksi perbenihan di PT. Sang Hyang Seri KR III dituntut gerak cepat terutama dalam hal operasional lapangan sehingga tingkat kerapian pekerjaan akan berbeda dengan pekerjaan yang bersifat administrasi.

Besarnya pengaruh langsung kemampuan terhadap kinerja karyawan adalah 19,18\%. Kemampuan memiliki pengaruh yang positif dan signifikan terhadap kinerja karyawan di Bagian Produksi yang berarti semakin baik kemampuan yang dimiliki karyawan di Bagian Produksi PT. Sang Hyang Seri maka kinerja karyawan akan semakin meningkat, atau sebaliknya, bila kemampuan karyawan yang dimiliki rendah di bagian Produksi PT. Sang Hyang Seri KR. III maka kinerja karyawan akan semakin menurun.

Skor rata-rata motivasi karyawan bagian produksi dapat dikategorikan tinggi. Teori motivasi / hierarkhi kebutuhan Maslow yang sesuai dengan pencapaian kinerja karyawan adalah Kebutuhan aktualisasi diri. Diperoleh ratarata skor tertinggi dalam aktualisasi diri adalah kesempatan mengikuti kursus. Hal ini dapat mendukung kemampuan karyawan untuk meningkatkan skill/ ketrampilannya, yang menunjukkan skor rata-rata terendah dalam variabel kemampuan karyawan. Sedangkan skor rata-rata terendah pada dimensi aktualisasi diri adalah pada kesesuain bidang pekerjaan dan pendidikan di segala bidang. Yang berarti perusahaan belum sepenuhnya dapat menempatkan karyawannya sesuai dengan potensi yang dimiliki, namun demikian potensi pada diri karyawan dapat tergali oleh berbagai macam latihan dan pengalaman kerja di segala bidang, sehingga perlu diberi kesadaran pada karyawan agar memanfaatkan kesempatan yang sekarang telah diperoleh untuk mengembangkan potensi yang ada pada dirinya. Pendidikan dan pelatihan yang sudah dilaksanakan dapat lebih ditingkatkan dengan materi 
yang bervariasi untuk menambah wawasan di semua bidang kegiatan. sehingga potensi karyawan dapat tergali dengan baik kemudian akan menumbuhkan kinerja yang baik pula.

Besarnya pengaruh langsung motivasi terhadap kinerja adalah 37,58\%. Kinerja yang tinggi dapat tercipta dengan semangat kerja atau motivasi karyawan yang tinggi untuk menyelesaikan pekerjaan, semakin tinggi motivasi karyawan maka kinerja yang dihasilkan semakin tinggi pula.

Selain kemampuan karyawan, motivasi kerja juga merupakan faktor yang penting dalam membentuk kinerja karyawan, hasil analisis Jalur sebesar menunjukkan bahwa motivasi mempengaruhi kinerja karyawan secara langsung sebesar 37,58\% Motivasi kerja juga memiliki pengaruh yang positif dan signifikan terhadap kinerja karyawan di PT. Sang Hyang Seri KR III, artinya semakin tinggi motivasi kerja karyawan maka kinerja karyawan akan semakin meningkat, atau sebaliknya, semakin rendah motivasi kerja karyawan maka kinerja karyawan akan semakin menurun. Ini dikarenakan dengan motivasi kerja karyawan yang tinggi maka pencapaian kinerja karyawan yang diinginkan akan dapat terwujud dengan baik.

Skor rata-rata pada kinerja karyawan juga sudah dapat dikategorikan tinggi, namun pelaksanaan pekerjaan secara efektif masih perlu ditingkatkan untuk lebih mendukung kinerja bagian produksi.

Pada dasarnya kinerja karyawan merupakan hal yang bersifat individual. Setiap karyawan akan memiliki tingkat kinerja yang berbeda-beda sesuai dengan potensi yang ada pada dirinya. Hal ini disebabkan adanya perbedaan pada masing-masing karyawan. Semakin banyak aspek-aspek dalam pekerjaan yang sesuai dengan keinginan individu tersebut, maka semakin tinggi tingkat kinerja yang dihasilkan dan sebaliknya.

Dari keempat dimensi dalam variabel kinerja, rata-rata skor yang paling tinggi ada pada konsistensi yaitu sebesar 4,27 atau $85,37 \%$ yang berarti bahwa karyawan bagian Produksi PT. Sang Hyang Seri KR IIII sangat konsisten dengan bidang pekerjaan yang digeluti.

Indikator yang paling tinggi kenirja karyawan dari dimensi konsistensi ini adalah instruksi pimpinan yaitu sebesar $88,42 \%$ dengan rata-rata skor 4,42 . Bila karyawan selalu menjalankan tugas sesuai dengan instruksi pimpinan maka ia dapat lebih menyelesaikan pekerjaannya yang pada akhirnya akan menghasilkan kinerja yang baik. Sementara indikator yang paling rendah pada dimensi konsistensi adalah penerapan ilmu teknologi persentase sebesar $79,47 \%$ dan rata-rata 
skor 3,97. Yang berarti bahwa penerapan teknologi masih harus ditingkatkan dengan melakukan banyak pelatihan dan pembinaan pada karyawan dalam menerapkan teknologi.

Apabila dimensi konsistensi memiliki rata-rata skor paling tinggi, lain halnya dengan dimensi Efektifitas. Dimensi Efektivitas ini memiliki rata-rata skor yang paling rendah yaitu sebesar 3,27 atau $65,39 \%$. Untuk dapat memberikan kontribusi yang lebih besar terhadap kinerja karyawan maka Bagian Produksi PT. Sang Hyang Seri KR III dapat mengusahakan agar pelaksanaan pekerjaan dapat dilakukan secara efektif dan seefisien mungkin, sehingga hasil yang diinginkan dapat maksimal dengan biaya yang dikeluarkan seminimal mungkin.

Kemampuan karyawan tidak hanya memiliki pengaruh secara langsung, tetapi juga memiliki pengaruh tidak langsung terhadap kinerja karyawan melalui motivasi kerja. Besarnya pengaruh langsung kemampuan terhadap kinerja karyawan adalah 19,18\% dan besarnya pengaruh kemampuan terhadap kinerja karyawan melalui motivasi (tidak langsung) adalah sebesar 16,67\%. Artinya para karyawan yang memiliki kemampuan tinggi akan menumbuhkan kepercayaan kepada dirinya sehingga terdorong/ termotivasi untuk melakukan kinerja yang baik.
Motivasi karyawan selain berpengaruh langsung terhadap kinerja, juga berpengaruh tidak langsung terhadap kinerja karyawan melalui kemampuan, sebesar $16,67 \%$ pula. Artinya motivasi karyawan yang tinggi dapat mendorong kemampuan karyawan untuk menghasilkan kinerja yang baik sebesar $16,67 \%$.

Dibandingkan kemampuan, motivasi kerja memiliki pengaruh lebih besar terhadap kinerja karyawan. Ini menunjukkan motivasi kerja memiliki pengaruh paling dominan terhadap kinerja. Hal ini dapat dilihat dari hasil analisis jalur bahwa motivasi dapat menjelaskan perubahan kinerja karyawan sebesar $37,58 \%$ dan kemampuan karyawan dapat menjelaskan perubahan kinerja karyawan sebesar 19,18\%. Hal ini dapat sebagai acuan perusahaan untuk lebih meningkatkan kemampuan masing-masing karyawannya, dengan meningkatkan pengalaman, pengetahuan, dan ketrampilan para karyawan

\section{KESIMPULAN}

Berdasarkan hasil dan analisis hasil penelitian dapat diperoleh beberapa kesimpulan yaitu:

1. Kemampuan karyawan Bagian Produksi di PT. Sang Hyang Seri KR III Wilayah Jawa Timur dapat dikategorikan tinggi. 
2. Motivasi kerja karyawan di Bagian Produksi PT. Sang Hyang Seri KR III Wilayah Jawa Timur dapat dikategorikan tinggi .

3. Kemampuan dan motivasi kerja berpengaruh terhadap kinerja karyawan di Bagian Produksi PT. Sang Hyang Seri (Persero) KR III Wilayah Jawa Timur.

a. Kemampuan dapat mempengaruhi kinerja karyawan secara langsung maupun tidak langsung melalui motivasi.

b. Motivasi dapat mempengaruhi kinerja karyawan, secara langsung maupun tidak langsung melalui kemampuan.

\section{DAFTAR PUSTAKA}

Algifari, 1997, "Analisis Statistik Untuk Bisnis", Yogyakarta, BPFE.

As'ad, M. 2003. Psikologi Industri : Sumber Daya manusia. Yogyakarta. Liberty.

Azwar, Saifuddin, 1997, Reliabilitas dan validitas. Yogyakarta. Penerbit Pustaka Pelajar.

Boyatzis, R.E. 1982. The Competent Manager a Model for Effective Performance. United State of America. John Wiley and Sons Inc,

Ghozali, Imam, 2001. Aplikasi Analisis Multivariate dengan program SPSS. Semarang : UNDIP

Hadi, S. 2004. Metodologi research, Jilid 1-4. Yogyakarta. Andi

Hasibuan, Malayu. 1995. Manajemen Sumber Daya Manusia, jakarta, CV. Haji Masagung.
Henry Simamora, 2006. Manajemen Sumberdaya Manusia. Yogyakarta. STIE YKPN.

Herminarto Sofyan, 2004. Teori Motivasi dan Aplikasinya dalam Penelitian. Gorontalo. Nurul Jannah.

http://www.pustaka_deptan.go.id

Istijanto, 2005. Riset Sumber Daya Manusia. Jakarta, PT. Gramedia, Binarupa Aksara.

Kreitner, Robert dan Kinicki Angelo. 2005. Perilaku Organisasi (Organizational Behavior) edisi ke5. Penterjemah : Erly Suandy. Penerbit Salemba Empat. Jakarta.

Moekijat, 2002. Dasar-Dasar Motivasi. CV. Pioner Jaya. Bandung.

Nawawi, 2005. Metode penelitian Bidang Sosial Ekonomi. Gadjah Mada University Press. Yogyakarta.

Nazir, 1998. Metode Penelitian. Jakarta. W I Press,

Rivai, Veithzal. 2005, "Performance Appraisal”. PT. Raja Grafindo Persada, Jakarta.

Robbins, S.P. 2006. Perilaku Organisasi (Edisi bahasa Indonesia), Edisi 10. Gramedia. Jakarta,

Robbins, Stephen $\mathrm{P}$ dan Coulter, Mary. 2002. Management, Sixth Edition.PT. Prenhallindo. Jakarta

Siagian SP. 2002. Manajemen sumberdaya Manusia. Bumi Aksara. Jakarta.

Sitepu, Nirwana SK. (1994). Analisis Jalur (Path Analysis). FMIPA Universitas Padjadjaran, Bandung.

Suwardie, 2007. Evaluasi Diklat Kewirausahaan dan Agribisnis di Pedesaan.. Kepel. Yogyakarta

Syafaruddin, 2001. Manajemen Sumberdaya Manusia "Strategi Keunggulan Kompetitif". BPFE UGM. Yogyakarta

Terry, George R.2006. Human Resources 
Management (seventh Edition).

Prince Hall. International Inc. London.

Tim Penyusun, 2008. Warta Penelitian dan Pengembangan Pertanian, Vol.30 no.5. Jakarta

Tim Penyusun. Company Profile : PT Sang Hyang Seri (Persero) Kantor Regional III. SHS. 2000. Malang

Vroom, V.H. 1964. Work and Motivation. John Willey and Sons.Inc. New
York.

Winardi, 2002. Motivasi \& Pemotivasian dalam Manajemen. Jakarta. Jakarta. PT. Raja Grafindo Persada, Jakarta.

Wirawan. 2003. Pengaruh Motivasi Terhadap Kinerja Karyawan, Studi Kasus pada PT . (Persero) Pelabuhan Indonesia III Cabang Tanjung Emas Semarang. http:// Pengaruh Motivasi Terhadap Kinerja. 2010. 